\title{
SIMULATION EVALUATION OF THERMAL PERFORMANCE OF SAH USING ARTIFICIAL ROUGHNESS
}

\author{
CHETAN JAISWAL ${ }^{1} \&$ DR. RAKESH BHANDARI ${ }^{2}$ \\ ${ }^{1}$ Ph D Research Scholar, Sangam University Bhilwara Rajasthan India \\ ${ }^{2}$ Associate Professor, Mechanical Engineering, Sangam University, Bhilwara, Rajasthan- India
}

\begin{abstract}
This work is based on CFD investigation of artificial roughness at regular interval in from of rib. CFD is a powerful tool to solve design problem by applying mathematical models. The objective of this article is to analysis of new design with simulation techniques. SAH is a device to convert solar energy to thermal energy by the use of artificial roughness. Ribs are use for producing artificial roughness. These ribs proposed to enhancement of thermal efficiency and heat transfer rate. Analysis is based on Bhilwara city in Rajasthan state. Bhilwara city is situated at $25.359854^{\circ} \mathrm{N}$ and $74.652791^{\circ} \mathrm{E}$. The average altitude of 421 meters (1381 feet). Rib is formed three internal sides of rectangular box. CFD is a tool to identifying optimal use of new design and finding fluid flow parameters like heat transfer, system efficiency, prediction of heat etc. In this work the complete analysis is performed on discrete-W $(D-W)$ rib. Solar air heater related Reynolds number is adopted (3000-17000). The present simulation analyses demonstrate that the RNG $k-\varepsilon$ model provides better results. Result gives major improvement in thermal efficiency and heat transfer with respect to smooth surface.

KEYWORDS: CFD, Discrete-W, Artificial Roughness, Reynolds Number. Thermal Efficiency
\end{abstract}

Received: Jun 08, 2020; Accepted: Jun 28, 2020; Published: Sep 10, 2020; Paper Id.: IJMPERDJUN20201148

\section{INTRODUCTION}

In the current scenario, the world facing a global energy crisis because oil and other conventional sources are nearer to finish and energy demands are increasing day by day. Depleting of fossil fuel has increased and increasing the demand of renewable energy. Solar energy has a good potential of filling the gaps in increasing demand. The solar air heater having low thermal convective heat transfer coefficient between absorber plate and circulating air. Artificial roughness is one of the most important methods to converting the solar energy to thermal energy[1]. After providing artificial roughness on the either one or both side of plate, heat transfer coefficient can enhance to provide system more successful. Artificial roughness are providing on brake the continues absorber plate by providing rib, grooves and combination of rib and grooves. Converting the solar energy to thermal energy is the most convenient way to utilize solar energy. The researchers are carried out in various researches on solar air heater for enhancing heat transfer by using artificial roughness[2]. Wide used of solar air heater in the field of space heating applications, heating process in industries. It has played an important role to fulfill energy demand as room heating and process industries. To receive best outputs in heating processes solar air heater is the most sensible device. Kumar and Kim [3] reported that v-pattern rib with a mixture type grooved roughness shape show better thermal-hydraulic performance than other comparable V-pattern rib roughness shapes. This is because grooves in the V-pattern ribs perk up the heat transfer and produce a higher level of turbulence in the fluid downstream. Chaube et. al. [4] they doing simulation an experimental analysis on heat transfer parameters and flow characteristics on artificial roughness creates on metal plate called rib. The plate is fitted in rectangular duct and air is interred in turbulence 
mode. Author takes varying Reynolds number 3000-20000. Singh et. al. [5] work on comparison of thermo hydraulic performance of V-down rib geometry with gap and similar rib geometries by earlier investigators has been done. Researcher use relative roughness pitch is 8 and Reynolde number range is 3000 to 12000. Maximum growth in Nusselt number and friction factor is 2.70 and 2.86, respectively. Momin et. al. [6] the researcher work has been done on experimental investigation of geometrical parameters of $\mathrm{V}$-shaped rib, applying different conditions of rectangular duct with solar air heater on absorber plate and doing study of heat transfer parameter and flow characteristic. Reynolde number, relative roughness, angle of attack relative pitch are $2500-18000,0.02-0.034,30^{\circ}-90^{\circ}$ and 10 respectively.

Aharwal et. al. [7] in this study, researcher presents experimental investigation of heat transfer and friction factor characteristics by using rectangular duct. The maximum enrichment of Nuselt number and friction factor is 2.59 and 2.87 times of the smooth duct, respectively. The overall results give maximum thermal hydraulic performance. Researcher found results and they compare with those of the smooth duct under similar flow conditions. Width to height ratio, reynolde number, relative roughness pitch, relative roughness height, angle of attack are 5.84, 3000 to 18,000, 10, 0.0377, $60^{\circ}$ respectively. Bhagoria et. al. [8] In researchers doing experimental performance on wedge shaped transverse integral rib. They developed Nusselt number and friction factor by the use of reynolds number, relative roughness height, relative roughness pitch and rib wedge angle are 3000 to $18000,0.015$ to $0.033,60.17$ and $8,10,12$ and $15^{\circ}$ respectively. Using these data researchers found results and they compare with those of the smooth duct under similar flow conditions. The statistical correlations of Nuselt number and friction factor. The overall results give maximum thermal hydraulic performance. Gawande et. al [9] in this research, researcher doing a review study on solar air heater and heat exchanger to improve the efficiency by using different shapes and size of absorbing plate geometry such as rib, dimple shape roughness, wire mesh, baffles, delta winglets. Researcher done the study of various roughness element geometries are employed in solar air heater and heat exchanger and developed correlation between heat transfer and friction factor for different geometries. Hans et. al [10] researchers says that, using underside artificial roughness of the absorber plate is a most effective and economic way to enhancement of thermal hydraulic performance of solar air heater. Experiment has been conducted on multi V-ribs, to collect data and study on heat transfer and fluid flow characteristics. Using above data in experimental studies, to develop correlations between Nuselt number and friction factor a per roughness geometry and flow criterion been developed. For the proven of above statement researcher done experimental study and using reynolds number, relative roughness height, relative roughness pitch, angle of attack and relative roughness width are $2000-20000$, $0.019-0.043,6-12,30^{\circ}-75^{\circ}$ and 1- 10, respectively. Karwa et.al. [11] experimental study on heat transfer parameters and friction flow condition on rectangular duct with repeated chamfered rib. Heat transfer rate increases with respect to aspect ratio from 4.65 to 9.66 and roughness decreases with increasing aspect ratio 4.65 to 7.75 . Layek et. al [12] study using mathematical model for identifying entropy generation in solar air heater on roughened absorber plate. Promvonge [13] in these study researchers done his work on $60^{\circ} \mathrm{V}$ baffles also studded on turbulent forced convection heat transfer and friction loss behaviors. Yadav et. al [14] done detailed review of literature that work based on CFD code ANSYS FLUENT (version 12.1) this article researchers assumed two dimensional flow. The researchers suggest a Renormalization-group $\mathrm{k}-\varepsilon$ model yields gives the best results for two- dimensional flow through conventional solar air heaters. Varun et.al [15] worked on experimental study on heat transfer and friction factor characteristics by using different type of rib. They used Reynolds number:- 2000 - 14000

Relative roughness height:- 0.030 , Relative roughness pitch :- 3 - 8, 
They used above parameters and put his results based on experimental study, the heat transfer and friction factor has been discussed with correlation of Nusselt number, the overall thermal performances is increased and gives maximum thermal efficiency when relative roughness pitch is 8. Yadav et. al [16] worked on CFD ANSYS FLUENT version 12 used two dimensional fluid flow and find heat transfer processes in a rectangular duct of a solar air heater achieving maximum results by RNG k- $\varepsilon$ turbulence model is give best results for given Reynolds number. Sethi et.al [17] experiment investigation on rough element of absorber plate. Aspect ratio:- 11, Reynolds number:- 3600 - 18000, Angle of attack:- 45 $-75^{0}$

Relative roughness height:- 0.021 - 0.036,Relative roughness pitch :- 10 - 20, observed significant enhancement in heat transfer and friction factor.

Table 1: A Summary of Literature Review

\begin{tabular}{|c|c|c|c|c|}
\hline Sr. No. & $\begin{array}{l}\text { Researcher / } \\
\text { Authors }\end{array}$ & $\begin{array}{l}\text { Computational domain and } \\
\text { model }\end{array}$ & Working Parameters & Simulations Results \\
\hline 1 & $\begin{array}{l}\text { Chaube et al } \\
{[22]}\end{array}$ & $\begin{array}{l}\text { Rectangular, circular, } \\
\text { semicircular ribs. } \\
\text { SST-k- } \varepsilon \text { model used and } \\
\text { analysis on 2D rectangular } \\
\text { duct. }\end{array}$ & $\begin{array}{c}\mathrm{R}_{\mathrm{e}}=3000-20000 \\
\mathrm{P} / \mathrm{e}=13.3, \mathrm{e}=3 \text {, heat } \\
\text { flux }=1100 \mathrm{~W} / \mathrm{m}^{2}\end{array}$ & $\begin{array}{l}\text { Found best performance, } \\
\text { using rectangular duct with } \\
\text { rib size } 3 \times 5 \mathrm{~mm}\end{array}$ \\
\hline 2 & $\begin{array}{l}\text { Kumar and } \\
\text { Saini[23] }\end{array}$ & $\begin{array}{l}\text { Circular wire rib in arc shape. } \\
\text { RNG- k- } \varepsilon \text { model used and } \\
\text { analysis on 3D model. }\end{array}$ & $\begin{array}{c}\mathrm{R}_{\mathrm{e}}=6000-18000, \\
\mathrm{P} / \mathrm{e}=10, \mathrm{e} / \mathrm{D}=0.0299 \\
\text { and } 0.0426, \text { heat } \\
\text { flux }=1000 \mathrm{~W} / \mathrm{m}^{2}, \\
\mathrm{~W} / \mathrm{H}=12, \\
\alpha=30^{\circ} \text { and } 60^{\circ}\end{array}$ & $\begin{array}{l}\text { The maximum overall } \\
\text { performance enhancement } \\
\text { ratio reported as } 1.7 \text { and } \\
\text { better thermal efficiency }\end{array}$ \\
\hline 3 & $\begin{array}{l}\text { Karmare et } \\
\text { al[24] }\end{array}$ & $\begin{array}{l}\text { Metal ribs of square, circular } \\
\text { and rectangular shape. } \\
\text { k- } \varepsilon \text { model used and analysis on } \\
\text { 3D model }\end{array}$ & $\begin{array}{c}\mathrm{R}_{\mathrm{e}}=3600-17000 \\
\mathrm{P} / \mathrm{e}=17.5, \mathrm{e} / \mathrm{D}= \\
0.044 \\
\alpha=60^{\circ}, \mathrm{l} / \mathrm{s}=1.72\end{array}$ & $\begin{array}{l}\text { The maximum heat transfer } \\
\text { by square rib, having angle } \\
\text { of attack is } 58^{0} \text {. }\end{array}$ \\
\hline 4 & Gandhi et al[25] & $\begin{array}{l}\text { Wedge shaped transverse rib. } \\
\text { k- } \varepsilon \text { turbulence model and } \\
\text { analysis on } 2 \text { D rectangular } \\
\text { SHA }\end{array}$ & $\begin{array}{c}\mathrm{R}_{\mathrm{e}}=5000-21000, \\
\mathrm{P} / \mathrm{e}=4.5, \mathrm{e} / \mathrm{D}=0.022, \\
\alpha=15^{0}\end{array}$ & $\begin{array}{l}\text { Roughened rib surface gives } \\
\text { better performance, also } \\
\text { much flatter velocity profiles } \\
\text { and higher turbulence } \\
\text { intensity. }\end{array}$ \\
\hline 5 & Sharma et al[26] & $\begin{array}{l}\text { V-shaped rib with rectangular } \\
\text { duct. } \\
\text { SIMPLE algorithm with 3D } \\
\text { rectangular duct model }\end{array}$ & $\begin{array}{c}\mathrm{R}_{\mathrm{e}}=5000-20000 \\
\mathrm{P} / \mathrm{e}=6-12 \\
\mathrm{e} / \mathrm{D}=0.0216-0.043 \\
\alpha=60^{\circ}\end{array}$ & $\begin{array}{l}\text { V-shaped roughened rib } \\
\text { increase the heat transfer rate } \\
\text { because perfect use of } \\
\text { swirling motion. }\end{array}$ \\
\hline 6 & Yadav et al[27] & $\begin{array}{l}\text { Transvers wire rib in circular } \\
\text { shape. } \\
\text { RNG- k- } \varepsilon \text { model used and } \\
\text { analysis on } 2 \mathrm{D} \text { rectangular } \\
\text { solar air heater duct model. }\end{array}$ & $\begin{array}{c}\mathrm{R}_{\mathrm{e}}=3800-18000 \\
\mathrm{P} / \mathrm{e}=7.14-35.71 \\
\mathrm{e} / \mathrm{D}=0.021-0.042 \\
\text { heat flux }=1000 \\
\mathrm{~W} / \mathrm{m}^{2}\end{array}$ & $\begin{array}{l}\text { Analysis result shows that } \\
\mathrm{P} / \mathrm{e}=10.71 \text { and } \mathrm{e} / \mathrm{D}-0.042 \\
\text { gives better thermal effects } \\
\text { for studied range of } \\
\text { Reynolds number. }\end{array}$ \\
\hline 7 & Yadav et al[28] & $\begin{array}{l}\text { Square-selected transvers rib. } \\
\text { RNG- k- } \varepsilon \text { model used and } \\
\text { analysis on } 2 \text { D rectangular } \\
\text { solar air heater duct model. }\end{array}$ & $\begin{array}{l}\mathrm{R}_{\mathrm{e}}=3800-18000 \\
\mathrm{P} / \mathrm{e}=7.14-17.86 \\
\mathrm{e} / \mathrm{D}=0.042\end{array}$ & $\begin{array}{l}\text { Analysis results shows finest } \\
\text { thermo-hydraulic } \\
\text { performance parameter was } \\
\text { found } 1.82 \text { for } \mathrm{p} / \mathrm{e}=10.71\end{array}$ \\
\hline 8 & Yadav et al[29] & $\begin{array}{l}\text { Triangular rib } \\
\text { RNG- k- } \varepsilon \text { model used and } \\
\text { analysis on 2D rectangular } \\
\text { solar air heater duct model. }\end{array}$ & $\begin{array}{l}\mathrm{R}_{\mathrm{e}}=3800-18000 \\
\mathrm{P} / \mathrm{e}=7.14-35.71 \\
\mathrm{e} / \mathrm{D}=0.021-0.042\end{array}$ & $\begin{array}{l}\text { Analysis shows prime charge } \\
\text { of thermo-hydraulic } \\
\text { parameter on } 2.11 \text { for } \mathrm{P} / \mathrm{e}= \\
7.14 \text { and } \mathrm{e} / \mathrm{D}=0.042\end{array}$ \\
\hline 9 & $\begin{array}{l}\text { Boulemtefus- } \\
\text { Boukadoum and } \\
\text { Benzaoui [30] }\end{array}$ & 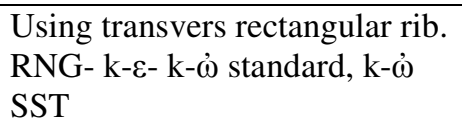 & $\begin{array}{c}\text { Aspect ratio }=7.5, \mathrm{e}= \\
3.4, \mathrm{w}=5.8, \mathrm{p}=34 \\
\mathrm{~mm}, \mathrm{H}=40 \mathrm{~mm}\end{array}$ & $\begin{array}{l}\text { Analysis results shows the } \\
\text { separation and reattachment } \\
\text { zones. }\end{array}$ \\
\hline
\end{tabular}




\begin{tabular}{|c|c|c|c|c|}
\hline 10 & Yadav et al[31] & $\begin{array}{l}\text { Using smooth duct. } \\
\text { RNG- k- } \varepsilon \text { model used and } \\
\text { analysis on 2D rectangular } \\
\text { solar air heater duct model. }\end{array}$ & $\begin{array}{c}\mathrm{Re}=3800-18000 \\
\mathrm{P} / \mathrm{e}=7.14-35.71 \\
\mathrm{e} / \mathrm{D}=0.021-0.042 \\
\text { heat flux }=1000 \\
\mathrm{~W} / \mathrm{m} 2\end{array}$ & $\begin{array}{l}\text { It shows a comparison } \\
\text { between numerical and } \\
\text { empirical relations }\end{array}$ \\
\hline 11 & Kumar et al [32] & $\begin{array}{l}\text { Using integrated roughness on } \\
\text { absorber plate for enhancement } \\
\text { of heat transfer rate. }\end{array}$ & $\begin{array}{c}\mathrm{Re}=3500-21000 \\
\mathrm{P} / \mathrm{e}=6-10 \\
\alpha=30^{0}-90^{\circ}\end{array}$ & $\begin{array}{l}\text { Analysis results and develop } \\
\text { relation between friction } \\
\text { factor and Nusselt number } \\
\text { also found heat transfer } \\
\text { conditions. }\end{array}$ \\
\hline 12 & Kumar et al [33] & $\begin{array}{l}\text { Using multiple-arc shaped on } \\
\text { absorber plate and investigate } \\
\text { of optimization of } \\
\text { thermal performance of solar } \\
\text { air heater }\end{array}$ & $\begin{array}{c}\mathrm{Ng}=1-3 \\
\mathrm{~d} / \mathrm{x}=0.3-0.9 \\
\mathrm{~g} / \mathrm{e}=0.5-1.5 \\
\mathrm{Re}=1100-19000\end{array}$ & $\begin{array}{l}\text { Analysis the relation } \\
\text { between friction factor and } \\
\text { Nusselt number also } \\
\text { optimize thermal } \\
\text { performance of system. }\end{array}$ \\
\hline 13 & Kumar et al [34] & $\begin{array}{l}\text { Using twisted rib type absorber } \\
\text { plate and investigated } \\
\text { stochastic analysis of solar air } \\
\text { heater also work for } \\
\text { optimization of efficiencies. }\end{array}$ & $\begin{array}{c}\mathrm{Re}=500-211000, \\
\mathrm{P} / \mathrm{e}=8, \\
\alpha=60^{\circ} \\
\mathrm{y} / \mathrm{e}=3\end{array}$ & $\begin{array}{l}\text { Analysis of exergetic } \\
\text { performance and found } \\
\text { relation between analytic and } \\
\text { experimental study. }\end{array}$ \\
\hline 14 & $\begin{array}{l}\text { Jain and } \\
\text { Lanjewar [35] }\end{array}$ & $\begin{array}{l}\text { Over view study on V-rib } \\
\text { roughness geometries with } \\
\text { different four v-ribs }\end{array}$ & $\begin{array}{c}\mathrm{Re}=3000-14000 \\
\mathrm{P} / \mathrm{e}=10-16, \\
\mathrm{~g} / \mathrm{e}=4 \\
\mathrm{w} / \mathrm{e}=4 \\
\alpha=60^{\circ}\end{array}$ & $\begin{array}{l}\text { Analysis and found relation } \\
\text { between old and new v-rib } \\
\text { and also found maximum } \\
\text { enhancement between } \\
\text { nusselt number and friction } \\
\text { factor. }\end{array}$ \\
\hline
\end{tabular}

After a wide study of the existing literature, some loops have been observed in enhancement of solar air heater capacity. Most of researchers are limited parameters on the performance of SAH. Literature reviews shows that the researchers are doing more work on SAH but very limited work has been done on optimization of design. Surface roughness and material is most vital parameter for enhancement of performance of SAH. A new three side roughened surface used in the duct for enhancement of heat transfer rate. This study capable to indentify new and better design of SAH.

\section{COMPUTATIONAL FLUID DYNAMICS}

Know a day's engineering simulation tools are a necessity for the devolvement of a wide range of new engineering products. Various new technologies are developed with the help of these numerical tools like a new type of aerospace products, customized automobiles, robotic arm, and many more CFD is one of them, a numerical modeling tool for the development of fluid-based engineering products. At present most of the products like heat exchanger, HVAC systems, medical instruments I.C. engine cylinder simulation, optimization all types of fluid-based products are optimized by using CFD tools. Most of the open-source and commercial CFD software is using a finite volume method for the discretization of CFD domain. In FVM, differential Volumes are inured to transform algebraic equations of partial differential governing equations. These differential volumes are final control volumes (cell/elements/mesh). The very first common step in FVM method has discredited the geometry (CFD domain) into non overlapping finite volumes using professional meshing tools.

After this step, all governing equation is transformed to these discrete elements by using an integration method to all elements. These integration methods, convert PDF into a discrete algebraic equation.

All depended variable is computed by using these algebraic equation in solver like Ansys Fluent, open foam and many more. Following process flow diagram shows that general process for the work. 


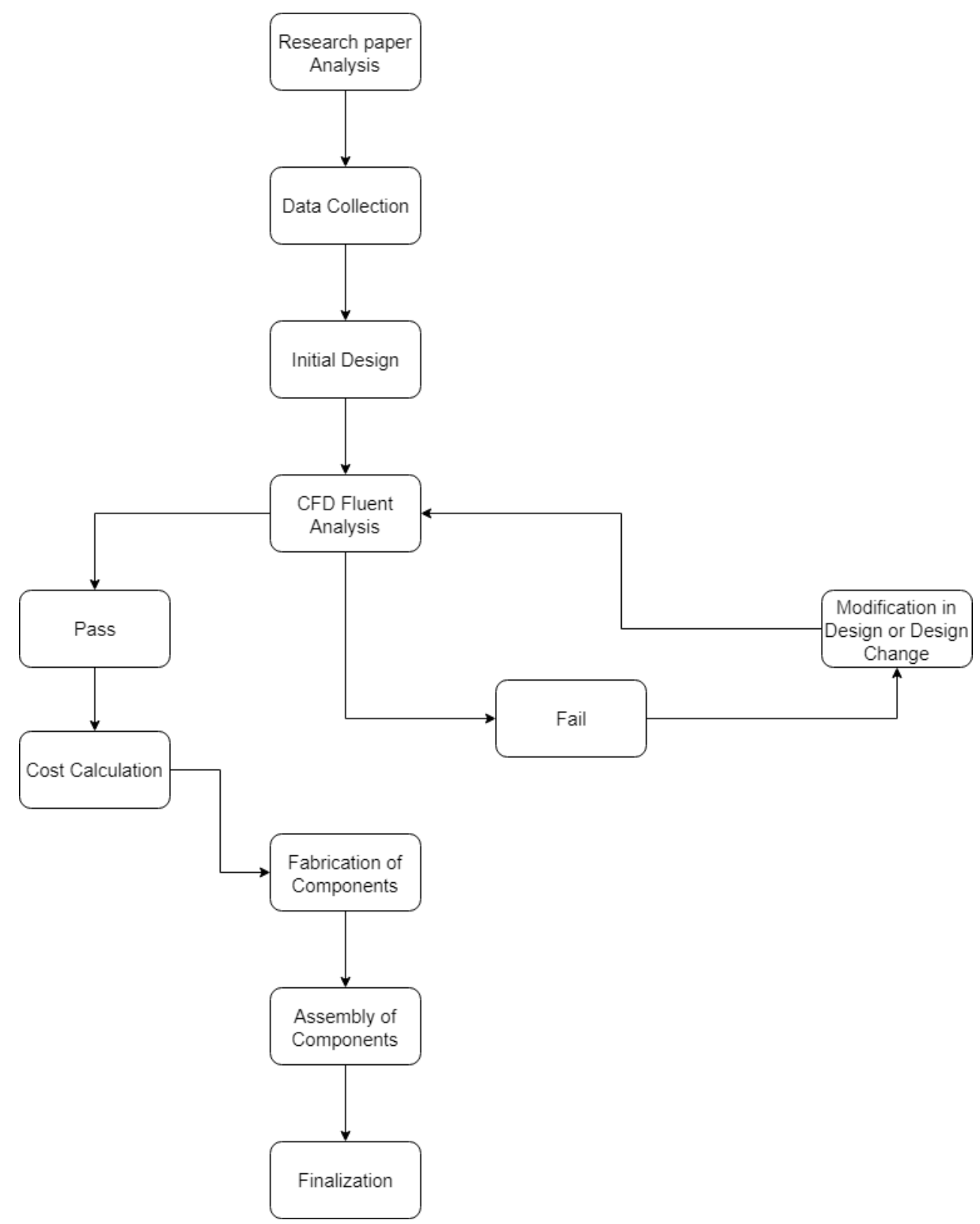

Figure 1: CFD Process Flow Chart.

\section{CFD ANALYSIS OF SAH}

Analysis has based on Bhilwara city in Rajasthan state. Bhilwara city is situated at $25.359854^{\circ} \mathrm{N}$ and $74.652791{ }^{\circ} \mathrm{E}$. The average altitude of 421 meters (1381 feet). The useful energy can be evaluated by equation 1 . The inlet and outlet air temperatures and the mass flow rate of air are observed. The energy gain is also the form of useful energy and the energy lost may be observed by equation 2. [18]

$$
\begin{aligned}
& \mathrm{Q}=\mathrm{mCp}\left(\mathrm{T}_{2}-\mathrm{T}_{1}\right) \\
& \mathrm{Q}=\mathrm{FR}(\tau \alpha) \text { ACI-FR X ULX AC }\left(\mathrm{T}_{1}-\mathrm{T}_{3}\right)
\end{aligned}
$$

\section{Energy Equations}

There is three medium for heat flow like conduction, convection, and radiation. Where Conduction is simple to simulate but convection and radiation are quite complex to simulate and all these heat transfer mediums are solved by using governing equations presented here. 


$$
\frac{\partial y}{\partial x}(\rho E)+\nabla \cdot\left(\nabla\left(\rho^{E}+p\right)=\nabla \cdot\left(k_{\text {eff }} \nabla T-\sum_{j} h_{j} J_{j}+(\tau e f f . V)\right)+S h\right.
$$

As shown in the equation, there are various assumptions are used in a study like steady-state, incompressible fluid flow, no radiation effect. So in the final form of the equation, it represents like

$$
\begin{aligned}
& \rho \frac{D E}{D t}=-\operatorname{div}(p u) \\
& +\left[\frac{\partial\left(u \tau_{w x}\right)}{\partial x}+\frac{\partial\left(u \tau_{w y}\right)}{\partial y}+\frac{\partial\left(u \tau_{w z}\right)}{\partial z}+\frac{\partial\left(v_{w y}\right)}{\partial x}+\frac{\partial\left(w_{w}\right)}{\partial y}+\frac{\partial\left(w_{z y}\right)}{\partial z}\right. \\
& \left.+\frac{\partial\left(w \tau_{z z}\right)}{\partial x}+\frac{\partial\left(w \tau_{y z}\right)}{\partial y}+\frac{\partial\left(w \tau_{g z}\right)}{\partial z}\right]+\operatorname{div}(\operatorname{Rgrad} T) \\
& E=i+\frac{1}{2}\left(u^{2}+v^{2}+w^{2}\right)
\end{aligned}
$$

\section{Conservation of Mass}

It can be also known as the continuity equation.

$$
\frac{\partial \rho}{\partial t}+\frac{\partial(\rho u)}{\partial x}+\frac{\partial(\rho v)}{\partial y}+\frac{\partial(\rho w)}{\partial z}=0
$$

Or in more compact vector notation

$$
\frac{\partial \rho}{\partial t}+d i v(\rho u)=0
$$

\section{Pumping Power}

The calculation of pumping power, friction factor and pressure loss are calculated by the following equations.[19]

$$
\begin{aligned}
& \delta \mathrm{p}=\left[(4 \mathrm{fL}) /\left(2 \rho \mathrm{D}_{\mathrm{h}}\right)\right] /(\mathrm{m} / \mathrm{WH})^{2} \\
& \mathrm{P}=(\mathrm{m} / \rho) \delta \mathrm{p}
\end{aligned}
$$

Equation 10 and 11 shows the absorber plate efficiency in useful energy to the total radiation on the collector surface.[20]

$$
\begin{aligned}
& \eta=\mathrm{Qu} / \mathrm{A}_{\mathrm{C}} \mathrm{I}=\mathrm{m} \operatorname{Cp}(\mathrm{To}-\mathrm{Ti}) /\left(\mathrm{IA}_{\mathrm{C}}\right) \\
& \eta=\mathrm{Qu} / \mathrm{A}_{\mathrm{C}} \mathrm{I}=\mathrm{F}_{\mathrm{R}}(\tau \alpha)-\mathrm{F}_{\mathrm{R}} \mathrm{U}_{\mathrm{L}}(\mathrm{Ti}-\mathrm{Ta}) / \mathrm{I}
\end{aligned}
$$

To find the collector performance by three criterion $F_{R}, U_{L}$ and $(\tau \alpha)$. These criterion depend on materials, flow conditions, construction and design of the collector. 


\section{RESULTS AND DISCUSSIONS}

Thermal performance evaluation is performed for this studied to verify the CFD simulation. In CFD is performed yearround solar condition in Ansys fluent software 19.0. Collector or absorber plate demonstration tests were conduct on days with clear sky conditions. The ambient temperature was between 30 and $40{ }^{\circ} \mathrm{C}$. The inlet temperatures to the four solar air collectors were similar to ambient temperature. The temperature differences between the inlet and outlet temperatures can be compared directly when determining the performance of the collectors. Since the amount of instantaneous radiation is the most important parameter in solar collectors, these changes are expected.[18]

The Ansys model is shown in figure 2 it indicates the flow of atmospheric air temperature at inlet and outlet conditions. Different locations of SHA are studied for temperature distributions. An inlet and outlet temperature are quiet different due to turbulence.

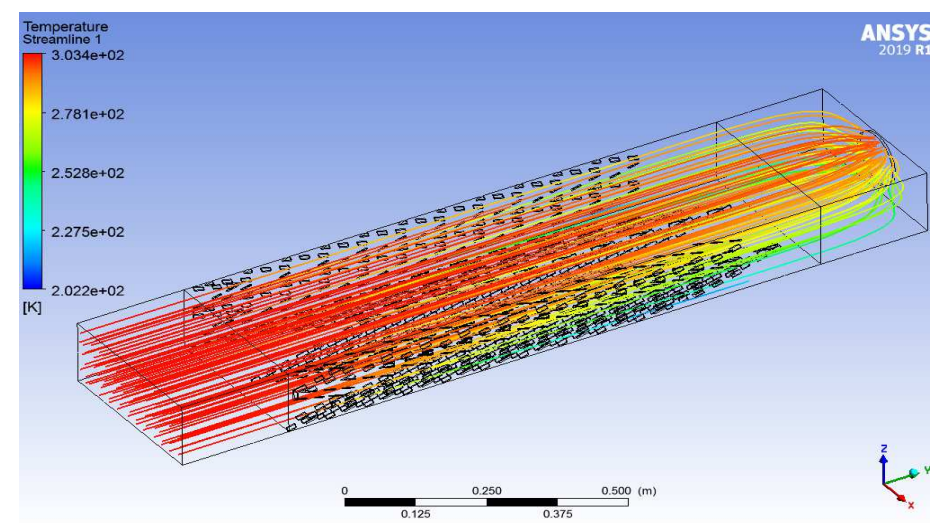

Figure 2: Temperature Contour of Three Side Discrete W-Shaped Fin.

Figure 3 are shows that, the selected areas are Glass plate, Absorber plate, inlet and outlet of solar air heater. The temperature is increases with respect to length or counters, it is play an important role to enhancement of thermal efficiency.

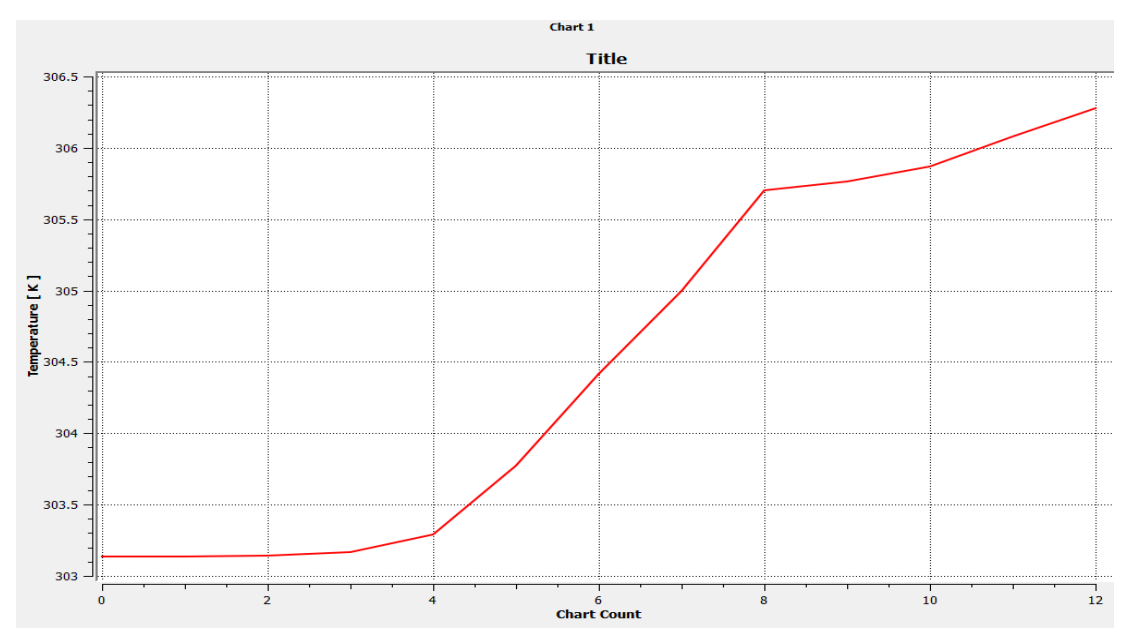

Figure 3: Temperature Parameter.

In the figure $4, \mathrm{Nu}$ number Shows that the performance of $\mathrm{SAH}$ is depended on months/ seasons of installed location. It presents the same results for a simple design for SAH. In this figure major months are included like January and December having low sun intensity so results shows less performance a compare to other months. 


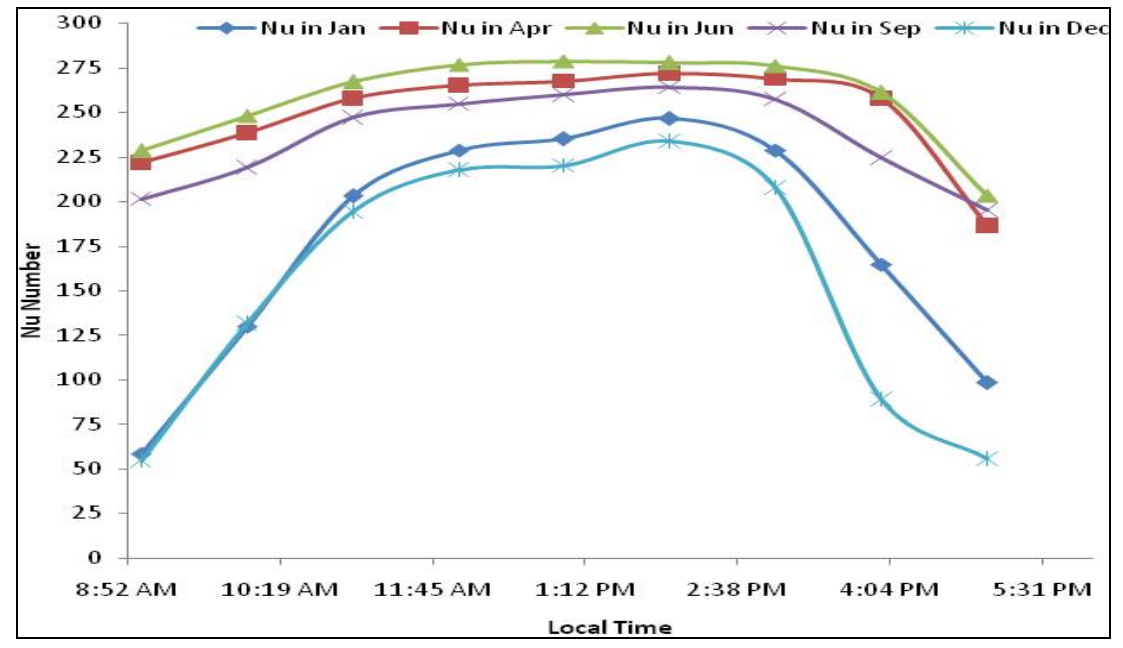

Figure 4: Year Around a Variation of Nusselt Number.

Figure 5 shows the outlet temperature for full-day condition and compared for all year analysis. It is month wise graph between temperature and local time, summaries way to understand. The thermal efficiency of the CFD design is presented in current study. In this figure major months are included like January and December having low sun intensity so results shows less performance a compare to other months.

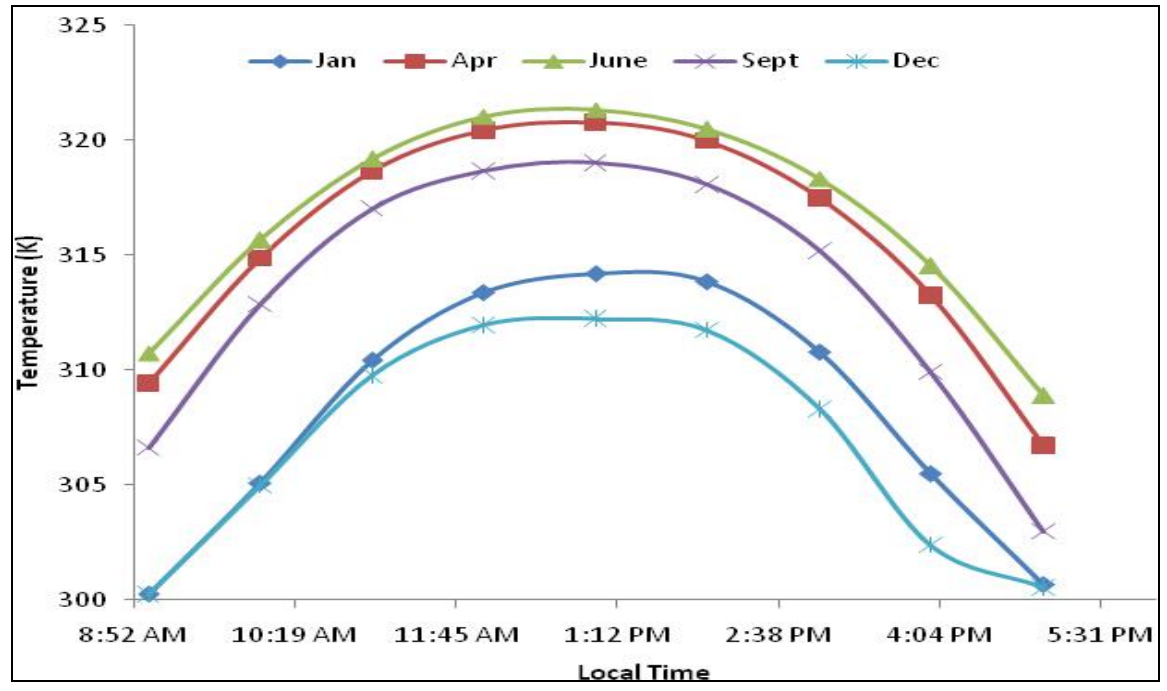

Figure 5: Year Around a Variation of Temperature.

Effect of thermal performance is defined in figure 6 CFD design. The highest thermal efficiency is achieved in June month at an afternoon session in between 12:00 noon to 03:00 pm. The thermal efficiency is improved in a range between $5-25 \%$. 


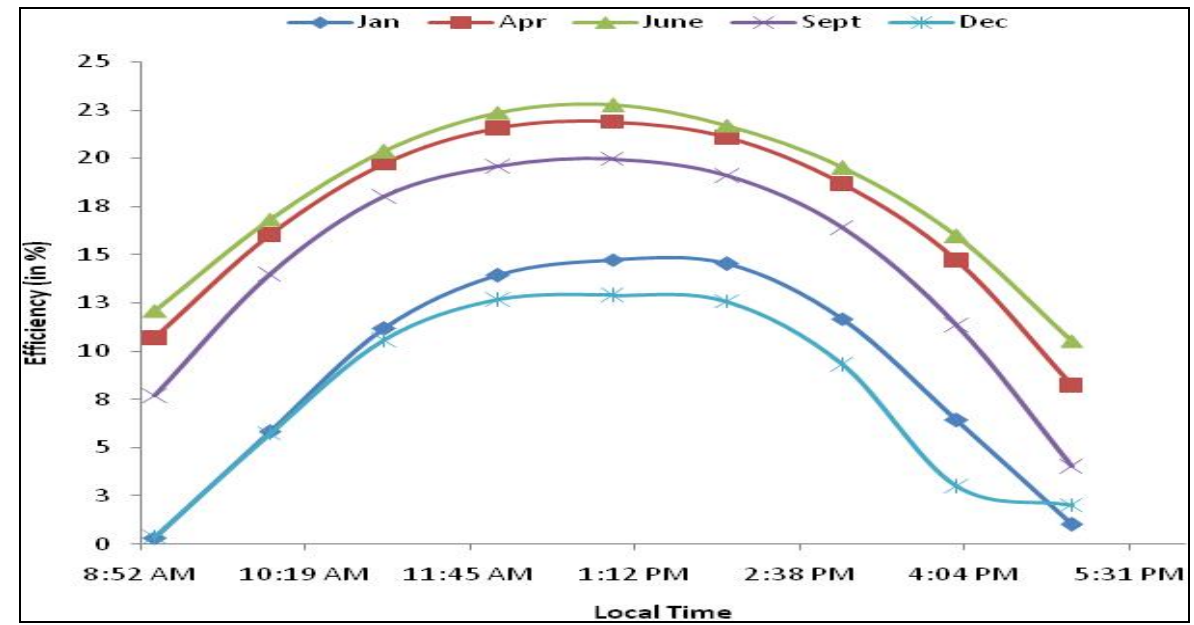

Figure 6: Variation in Thermal Performance.

The purpose of this analysis is to check the effect of designs of SAH having different atmospheric conditions of an absorber plate.

\section{CONCLUSIONS}

The present simulation analyses demonstrate that the RNG k- $\varepsilon$ model provides better results. This analysis shows best design of solar sir heater. A new three side roughened surface used in the duct for enhancement of heat transfer rate. This study capable to indentify new and better design of SAH. Assumed, a two-dimensional flow in CFD analysis. On the basis of present analysis the following conclusions are observed:

- $\quad$ CFD results are found better arrangement of ribs and provide better heat transfer rate.

- Surely, CFD analysis of solar air heater is improved design process and performance.

- Selection of simulation tool is very challenging task for design of solar air heater.

- Peaks of local heat transfer are found at the reattachment points.

- Turbulence intensity is found maximum, this turbulence peak of the local heat transfer coefficient in the inter-rib regions.

- In CFD analysis provide better heat transfer rate and thermal efficiency of SAH is improved.

\section{REFERENCES}

1. Rajesh Maithani, J.S. Saini, "Heat transfer and friction factor correlations for a solar air heater duct roughened with v-rib with symmetrical gaps" experimental thermal fluid science 70(2016) 220-227.

2. Yadav AS, Bhagoria JL "Modeling and simulation of turbulent flows through a solar air heater having square-sectioned transverse rib roughness on the absorber plate”. Sci World J 2013:1-12:

3. Anil Kumar and Man-Hoe Kim, "Heat transfer and fluid flow characteristics in an air duct with various V-pattern rib roughness on the heated plate: A comparative study", Energy, Elsevier Ltd., 0360-5442, 2016: 75-85.

4. Alok Chaube, P.K. Sahoo, S.C. Solanki "Analysis of heat transfer augmentation and flow characteristics due to rib roughness over absorber plate of a solar air heater" Renewable Energy 33 (2008) 585-596. 
5. Sukhmeet Singh, Subhash Chander, J.S. Saini "Heat transfer and friction factor correlations of solar air heater ducts artificially roughened with discrete V-down ribs" Energy 36 (2011) 5053-5064.

6. Abdul-Malik Ebrahim Momin, J.S. Saini, S.C. Solanki "Heat transfer and friction in solar air heater duct with V-shaped rib roughness on absorber plate" International Journal of Heat and Mass Transfer 45 (2002) 3383-3396.

7. K.R. Aharwal, B.K. Gandhi, J.S. Saini "Experimental investigation on heat-transfer enhancement due to a gap in an inclined continuous rib arrangement in a rectangular duct of solar air heater" Renewable Energy 33 (2008) 585-596.

8. J.L. Bhagoria, J.S. Saini, S.C. Solanki "Heat transfer coefficient and friction factor correlations for rectangular solar air heater duct having transverse wedge-shaped rib roughness on the absorber plate" Renewable Energy 25 (2002) 341-369.

9. Vipin B. Gawande, A.S. Dhoble, D.B. Zodpe "Effect of roughness geometries on heat transfer enhancement in solar thermal systems - A review" Renewable and Sustainable Energy Reviews 32 (2014) 347-378

10. V.S. Hans, R.P. Saini, J.S. Saini "Heat transfer and friction factor correlations for a solar air heater duct roughened artificially with multiple v-ribs" Solar Energy 84 (2010) 898-911

11. S.V. Karmare, A.N. Tikekar "Heat transfer and friction factor correlation for artificially roughened duct with metal grit ribs" International Journal of Heat and Mass Transfer 50 (2007) 4342-4351

12. R Karwa, S, C. Solanki, J.S. Saini "Heat transfer coe.cient and friction factor correlations for the transitional flow regime in rib-roughened rectangular ducts" International Journal of Heat and Mass Transfer 42 (1999) 1597-1615

13. Apurba Layek, J.S. Saini, S.C. Solanki "Second law optimization of a solar air heater having chamfered rib-groove roughness on absorber plate" Renewable Energy 32 (2007) 1967-1980

14. Pongjet Promvonge "Heat transfer and pressure drop in a channel with multiple $60^{\circ}$ V-baffles" International Communications in Heat and Mass Transfer 37 (2010) 835-840

15. Anil Singh Yadav, J.L. Bhagoria "A numerical investigation of square-sectioned transverse rib roughened solar air heater" International Journal of Thermal Sciences 79 (2014) 111-131

16. Varun, R.P. Saini, S.K. Singal "Investigation of thermal performance of solar air heater having roughness elements as a combination of inclined and transverse ribs on the absorber plate" Renewable Energy 33 (2008) 1398-1405

17. Anil Singh Yadav, J.L. Bhagoria "Heat transfer and fluid flow analysis of solar air heater: A review of CFD approach" Renewable and Sustainable Energy Reviews 23 (2013) 60-79

18. Muneesh Sethi, Varun, N.S. Thakur "Correlations for solar air heater duct with dimpled shape roughness elements on absorber plate" Solar Energy 86 (2012) 2852-2861

19. Ebru Kavak Akpinar, Fatih Koçyiğit. "Experimental investigation of thermal performance of solar air heater having different obstacles on absorber plates" International Communications in Heat and Mass Transfer 37 (2010) 416-421

20. Rajendra Karwa, Girish Chitoshiya. "Performance study of solar air heater having v-down discrete ribs on absorber plate" Energy 55 (2013) 939-955

21. J.A. Duffie, W.A. Beckman, Solar Engineering of Thermal Processes, second ed. John Wiley and Sons Inc, New York, 1991.

22. Chaube A, Sahoo PK, Solanki SC, "Analysis of heat transfer augmentation anf flow characteristics due to rib roughness over absorber plate of a solar air heater”. Renew Energy 31(3):317-331: 2006.

23. Kumar S, Saini RP "CFD based performance analysis of a solar air heater duct provided with artificial roughness". Renew Energy 34:1285-1291: 2009. 
24. Karmare SV, Tikekar AN "Analysis of fluid flow and heat transfer in a rib grit roughened surface solar air heater using CFD”. Sol Energy 84(3):409-417: 2010.

25. Gandhi BK, Singh KM "Experimental and numerical investigations on flow through wedge shape rib roughened duct". Inst Eng (India) J 90:13-18: 2010.

26. Sharma AK, Thakur NS “CFD based fluid flow and heat transfer analysis of a V-shaped roughened surface solar air heater". Int J Engg Science Technology 4(5):2115-2121: 2012.

27. Yadav AS, Bhagoria JL A "CFD (computational fluid dynamics) based heat transfer and fluid flow analysis of a solar air heater provided with circular transverse wire rib roughness on the absorber plate”. Energy 55:1127-1142: 2013.

28. Yadav AS, Bhagoria JL "Numerical investigation of flow through an artificially roughened solar air heater". Int J Ambient Energy 36(2):87-100: 2015.

29. Yadav AS, Bhagoria JL "A CFD based thermo-hydraulic performance analysis of an artificially roughened solar air heater having equilateral triangular sectioned rib roughness on the absorber plate”. Int J Heat Mass Transfer 70:1016-1039:2014.

30. Boulemtefus-Boukadoum A, Benzaoui A "CFD based analysis of heat transfer enhancement in solar air heater provided with transverse rectangular ribs”. Energy Proc. 50:761-772: 2014.

31. Yadav AS, Bhagoria JL "A CFD based heat transfer and fluid flow analysis of a conventional solar air heater". Journal of Engineering, Science \& Management Education 6(2):137-146: 2013.

32. Anup Kumar, Apurba Layek "Nusselt number and friction factor correlation of solar air heater having twisted-rib roughness on absorber plate" Renewable Energy S0960-1481(2018)30728-6.

33. Rajneesh Kumar, Varun Goel, Paramvir Singh, Abhishek Saxena, Abhishek Singh Kashyap, Amit Rai "Performance evaluation and optimization of solar assisted air heater with discrete multiple arc shaped ribs" Journal of Energy Storage 26 (2019) 100978.

34. Anup Kumar, Apurba Layek "Energetic and exergetic performance evaluation of solar air heater with twisted rib roughness on absorber plate” Journal of Cleaner Production 232 (2019) 617-628.

35. Piyush Kumar Jain, Dr.Atul Lanjewar “Overview of v-rib geometries in solar air heater and performance evaluation of a new v-rib geometry" Renewable Energy S0960-1481(18)31185-6.

36. Richard B Luhulima, "An Investigation into the Resistance of Displacement Trimaran:A Comparative Analysis Between Experimental and CFD Approaches “, International Journal of Mechanical Engineering (IJME), Vol. 6, Issue 5,pp. 9-18

37. Vivek Bharat Pattni, P. Naveenchandran, C. Thamotharan\& R. Rajasekar, "HCCI Combustion: Mathematical Modelling Approach Using Visual Basic for Applications “, BEST: International Journal of Management, Information Technology and Engineering (BEST: IJMITE), Vol. 2, Issue 5, pp. 1-8

38. Suresh Pittala \& Awash Tekle Tafere , “CFD Analysis for Linear Blade Cascade of a Turbine “, International Journal of Mechanical Engineering (IJME), Vol. 3, Issue 3, pp. 37-46

39. Kavindra Kumar Singh \& Praveen Kumar , “A Model for Website Quality Evaluation - A Practical Approach “, IMPACT: International Journal of Research in Engineering \& Technology (IMPACT: IJRET), Vol. 2, Issue 3, pp. 61-68 


\section{ANNEXURE 1}

\section{Nomenclature}

- $\quad \mathrm{AC}$ Area of absorber plate $\left(\mathrm{m}^{2}\right)$

- $\mathrm{CP}$ Specific heat at constant pressure $(\mathrm{kJ} / \mathrm{kg} \mathrm{K})$

- $\mathrm{F}_{\mathrm{R}}$ Collector heat removal factor at air inlet temperature (dimensionless)

- $\mathrm{F}_{\mathrm{o}}$ Collector heat removal factor at an air outlet temperature (dimensionless)

- $\mathrm{m}$ Mass Flow Rate $(\mathrm{kg} / \mathrm{s})$

- I Solar Radiation (W/m2)

- $\quad \mathrm{Qu} \quad$ Heat Rate $(\mathrm{kW})$

- $\quad \mathrm{T} \quad$ Temperature $\left({ }^{\circ} \mathrm{C}\right)$

- UL Collector overall heat loss coefficient $\left(\mathrm{W} / \mathrm{m}^{2 \circ} \mathrm{C}\right)$

- Dh Duct Hydraulic Diameter m

- W Duct Width, m

- w Rib Width, mm

- h Heat transfer coefficient, W/ $/ \mathrm{m}^{2} \mathrm{~K}$

- $\mathrm{H}$ Duct Height of Airflow (depth), m

- $\quad$ p Pitch Rib, m

- P Pumping Power, W

- $\mathrm{P} / \mathrm{e}$ Relative roughness Pitch

- e/D Relative roughness height

- $\quad \mathrm{Ng} \quad$ Number of gab

- $\mathrm{d} / \mathrm{x}$ Relative gap position

- g/e Relative gap width

\section{Greek Letters}

- $\quad \alpha$ Angle of attack absorptivity

- $\quad \eta \quad$ Thermal efficiency

- $\quad \tau \alpha$ Effective transmission

\section{Subscripts}

- 3 Ambient 
- Inlet

- Outlet

ANNEXURE 2

Table 2: Month Wise Thermal Efficiency

\begin{tabular}{|c|c|c|c|c|c|}
\hline Flow Time & January & April & June & September & December \\
\hline 9:00 AM & 10.70 & 26.37 & 17.88 & 21.43 & 10.70 \\
\hline 10:00 AM & 16.01 & 30.95 & 22.34 & 27.11 & 13.01 \\
\hline 11:00 AM & 19.71 & 34.10 & 25.44 & 32.59 & 16.71 \\
\hline 12:00 PM & 21.53 & 35.82 & 26.87 & 32.67 & 20.03 \\
\hline 1:00 PM & 21.88 & 36.22 & 27.29 & 31.57 & 20.88 \\
\hline $2: 00$ PM & 21.07 & 35.60 & 27.49 & 29.31 & 19.07 \\
\hline 3:00 PM & 18.66 & 32.87 & 25.10 & 24.98 & 15.66 \\
\hline 4:00 PM & 14.69 & 29.29 & 27.09 & 18.42 & 13.69 \\
\hline 5:00 PM & 8.23 & 29.32 & 28.56 & 13.29 & 6.23 \\
\hline
\end{tabular}

Table 3: Outlet Air Temperature

\begin{tabular}{|c|c|c|c|c|c|}
\hline Flow Time & January & April & June & September & December \\
\hline 9:00 AM & 309.41 & 324.02 & 319.29 & 319.22 & 309.41 \\
\hline 10:00 AM & 314.86 & 329.77 & 326.49 & 325.69 & 314.86 \\
\hline 11:00 AM & 318.65 & 333.44 & 330.94 & 331.51 & 318.65 \\
\hline 12:00 PM & 320.43 & 335.28 & 331.45 & 331.75 & 320.43 \\
\hline 1:00 PM & 320.76 & 335.67 & 332.86 & 328.70 & 320.76 \\
\hline 2:00 PM & 319.98 & 335.01 & 332.01 & 319.49 & 319.98 \\
\hline 3:00 PM & 317.48 & 331.93 & 330.37 & 318.97 & 317.48 \\
\hline 4:00 PM & 313.25 & 327.37 & 319.71 & 312.02 & 313.25 \\
\hline 5:00 PM & 306.71 & 320.55 & 319.19 & 309.12 & 306.71 \\
\hline
\end{tabular}



